\title{
The Role of the Geographical Textbooks in Grounding Negative Stereotypes of a Tourism Destination-The Case of Upper Silesian Conurbation in Poland
}

\author{
Mariusz Szubert ${ }^{\dagger}$ and Michał Żemła *,† \\ Department of Tourism and Regional Studies/Institute of Geography, Pedagogical University in Cracow, \\ 30-084 Cracow, Poland; mariusz.szubert@up.krakow.pl \\ * Correspondence: michalzemla@up.krakow.pl \\ + These authors contributed equally to this work.
}

Received: 12 May 2019; Accepted: 11 June 2019; Published: 15 June 2019

\begin{abstract}
Tourists' decisions on selecting their destinations are driven by their imagination of available offers, rather than by the real offers. The special role of the image of tourism destination in the process of building a competitive position result, among other things, comes from the fact the image is a factor of competitiveness influenced by both intentional and accidental actions of entities, whom are active in a particular tourism destination as well as environmental elements, which are beyond the influence of these entities. The cities of the Upper Silesian Conurbation were for many years perceived as completely dominated by heavy industry. Nowadays, after significant changes in their economy and environment, local authorities are struggling to fight that negative perception. The aim of the paper is to examine if the negative image of the Conurbation is grounded by the textbooks for geography for secondary schools in Poland. The textbooks were studied using the content analysis as an example of important autonomous sources of information. Particular stress was put on analysis of the heading and pictures in the chapters on the Conurbation. The results prove that industrial image of the region is being grounded by the geography textbooks. It was discovered that the picture of Upper Silesian Conurbation that might be found in researched textbooks is almost identical with what was previously presented in the literature as tourists' perception of the Conurbation. The results prove the role of the textbooks and the whole school education as factors shaping the image of particular places that people have also as adults. That role was neither researched nor clearly stated in the literature so far.
\end{abstract}

Keywords: destination image; negative stereotypes; post-industrial cities development; Upper Silesian Conurbation

\section{Introduction}

Different places compete on the tourism market to attract visitors (Crouch and Ritchie 1999). Creating an attractive, competitive offer is not an easy task, as potential customers do not have extended knowledge about competing destinations and do not have opportunity to test the product offered before consuming it (Enright and Newton 2004). So, tourists' decisions on selecting their destinations are driven by their imagination of available offers rather than by the real offers (Kock et al. 2016). Establishing distinctive and competitive image became crucial for destinations competing to attract visitors (Chi and Qu 2008; Pike and Mason 2011; Pike 2018) and destinations' marketers attempted to influence that image (Selby and Morgan 1996; Chen and Tsai 2007; Lai and Vinh 2012). However, establishing the desired image is difficult due to a series of reasons (Echtner and Ritchie 1991; Gallarza et al. 2002; Pike 2018). Among them, the fact that a destination image is based on both information dependent and independent from purpose marketing actions, is one the most important 
(Tasci and Gartner 2007). Potential tourists learn about features of particular places during their education, from media and from friends and relatives, and those messages are completely independent from the destination and their marketing strategies. The tourists' low level of knowledge (Tapia 2017) and the simplified messages sent through mass (including social) media, make stereotypes about particular places even more firmly rooted. Those stereotypes do not often make attracting visitors easier, as they present particular places in a very simplified (Chen et al. 2016; Avraham 2018), one-dimensional and often negative way (Muhwezi et al. 2016). Making an image of a destination more firmly rooted and/or changing it is a difficult and time-wasting task, which influences the rooted needs of the stereotypes with even more effort and time (Chen et al. 2012). It can even happen that the feature of the place, which is the base for the stereotype, was weakened or even disappeared from the real world, while the stereotype still exists in people's mind although the place representatives undertake actions to communicate the change.

The paper is devoted to analysis of a region where this really happens. The cities that are the part of Upper Silesian Conurbation were perceived for many years as completely dominated by heavy industry, and, in particular, coal mines, and that image was right. However, after systemic changes in Poland in the early nineties, coal mining and the heavy industry as a whole became economically less profitable; these cities started changing their economy and landscape step by step. Nowadays, in particular Katowice, the capital city of the region, is a modern and dynamic city, similar to many other cities of the same size in Poland and the industry here is modern and plays a secondary role in its economy, after services and new technologies. However, the situation is more differentiated in other cities of the Conurbation, and in some of them, coal mines and ironworks are still playing an important role in their economies and societies.

The industrial image of particular cities and of the Conurbation as a whole brought many associations which are extremely undesired for the image of an attractive tourist destinations. Those associations are usually connected with dirt, pollution and the general perception of an unattractive place to spend the time. Authorities of Katowice and of other cities, as well as regional authorities of Silesian Voivodeship, spent a lot of effort to communicate a new, modern and attractive nature of the Conurbation, but the research presented in the literature proves that these actions are far from being efficient (TNS Polska 2014; Hendel and Żemła 2015; Szubert and Żemła 2019). For example, young people who study in Krakow, located less than a $100 \mathrm{~km}$ from Katowice, presented a rather negative image of the Conurbation as a tourism destination and their responses proved that an industrial, negative stereotype of the region is still deeply rooted (Szubert and Żemła 2019). The aim of the paper is an attempt to examine if the negative image of the Conurbation is grounded, among others, by the school textbooks for geography in Poland. The textbooks were studied using the content analysis as an example of important autonomous sources of information. Apart from the destination image and stereotype literature review, which was the starting point of the paper and a short description of the Conurbation, it contains three major parts. The first one is connected with the results of researches of the image of the Conurbation which were already presented in the literature. The second one is an analysis of marketing actions and strategies implemented by local and regional authorities in order to make the Conurbation an attractive and competitive tourist destination. Finally, the third and most important one, is a presentation of the results of the content analysis of school textbooks that shows how the Conurbation is presented to pupils in the school education.

\section{Tourism Destination Image and Its Formation Process}

An image is perceived as a very important element of contemporary marketing. After gaining a big popularity on traditional tangible goods and services markets, the issue of an image also became a point of interest, and later on it even became a focal point in place marketing, including tourism destinations marketing. According to a widely cited definition by John Crompton (Crompton 1979, p. 18), "destination image" is "the sum of beliefs, ideas and impressions that a person has of a destination". Tourism researchers have frequently examined the concept of destination image (Pike and Ryan 2004). 
A number of tourism studies have shown the theoretical and practical importance of destination image (Beerli and Martín 2004; Echtner and Ritchie 1991; Souiden et al. 2017; Pike 2018); however, most tourism researchers also agree that the nature of destination image is too complex to be fully understood (Beerli and Martín 2004; Gallarza et al. 2002; Chen et al. 2012).

Therefore, an image can be an essential factor that builds the market position of the tourist reception area (Enright and Newton 2004). On the other hand, an unfavorable image may also be a significant limitation in tourism development in a given tourism destination. In some destinations that meet all conditions to serve tourism, it is particularly easy to see that these areas are still relatively unknown to potential tourists who are driven by unfavorable stereotypes (Avraham and Ketter 2017) rather than by real facts. Stereotypes of this kind are also the case on the international tourism market where most potential tourists are aware that there are many attractive countries and regions, but what they really know about their tourist offer, natural conditions and the history of all these countries is much too little.

The special role of the image of tourism destination in the process of building a competitive position results, among other things, comes from the fact that image is a factor of competitiveness influenced by both intentional and accidental actions of entities who are active in a particular tourism destination, as well as environmental elements that are beyond the influence of these entities (Chen et al. 2017). One of the issues that are particularly important for using the image in building a competitive position of tourism destination properly is to understand the nature of dependent and independent factors in the process of image formation of tourism destination. The process of image formation of tourism destination is defined in literature as creating a mental ideas image, representation of tourism destination based on information cues provided by image formation agents and selected by a specific person (Tasci and Gartner 2007). As part of the research on the process of image formation of tourism destination, according to Baloglu and McCleary (1999), Gallarza et al. (2002) indicate two approaches used in the literature. Numerous researchers referred to a strong positive relationship between both the image of individual attributes with the holistic image of tourism destination and the behavior of the buyer both before, during and after the tourist trip. (Ross 1993; Chen and Kerstetter 1999; Chen and Hsu 2000).

The model of image formation of tourism destination, which takes into account both the causes and the effects of the image of tourism destination, was presented by Tasci and Gartner (2007). The basic assumption underlying the model discussed is the statement that the image of tourism destination consists of elements originating from an individual and from elements of tourism destination. Three sources of factors that shape the image of the tourism destination were distinguished: the destination itself, independent sources and the recipient. A similar concept was presented earlier by (Gunn 1972) who identified two levels for the image of a tourist destination based on the type of information transmitted to the tourist—organic and induced images. According to (Gunn 1972), during the process of destination-image formation, organic images are first formed based on non-commercial information sources. That of organic and induced destination image was later used by numerous researchers (Chung et al. 2016).

An organic image is created by all information transmitted unintentionally. This information may be transmitted either via television, radio, books on geography or history, newspapers, magazines, or by people living at a tourist destination. As people tend to consider information from non-commercial sources as credible knowledge, organic images have a strong influence on how people evaluate a tourist destination image (Gartner 1994; Fakeye and Crompton 1991; Tasci and Gartner 2007; Chung et al. 2016; Chen et al. 2017). An induced image is an image formed by promotions and communications of the tourism organizations involved in a particular region. In this context, it is naturally true that both reference or membership groups and opinion leaders can powerfully influence the way tourists perceive a particular destination (Lopes 2011, p. 310). This statement also indicates not only that the promotional message of tourism destination should be carefully prepared, but also indicates that 
it should be followed how it is presented in independent messages, in the media, in the education process and other processes.

As it is noticed by Charlotte Echtner and Brent Ritchie (Echtner and Ritchie 1991, p. 38), a greater part of majority of products and services, information sources is of commercial nature. Destination images, however, seem to be derived from a much wider spectrum of information sources. This means that the information gleaned from non-commercial sources concerning various historical, political, economic and social factors is incorporated into destination image and plays an important role, which is much more substantial than it is for many other products. This is also the reason why it is so important to analyze the formulation of the organic image of a destination. However, there are not too many examples of scientific analysis of an organic image of a tourism destination as well as of marketing practices used to reconstruct the image based on an analysis like this. Among rare examples, works by Selby and Morgan (1996), Lepp et al. (2011) and Choi et al. (2007) can be pointed out.

The image that prospect visitors derive from autonomous sources, both media, education and private ones (friend, relatives) can stimulate rooting of positive or negative stereotypes of a particular destination. Additionally, the existing stereotypes might also become rooted more firmly that way. Negative stereotypes created and being sustained that way might be extremely difficult to get rid of for destination marketers and their commercial messages. Still, the issue of sources of these negative stereotypes, of their influences on a destination image and finally on customers' market behavior were not studied thoroughly so far (Avraham 2018). Single works dealing with that issue like works by Di Marino (2008), by Avraham (2018), by Chen et al. (2012) and by Fu et al. (2016) deal rather with images of particular countries on the international tourism market rather than with images of regions on the domestic market.

\section{Upper Silesian Conurbation}

The Upper Silesian Conurbation is located in southern Poland, in the central part of the Silesian Voivodeship. It is the largest urban-industrial area in Poland. The cities of today's Conurbation were formed along with the GOP [Górnośląski Okręg Przemysłowy-Upper Silesian Industrial District]. Its origins and development since the end of the 18th century was associated with coal mining and ferrous metallurgy. The Conurbation consists of 19 cities inhabited by 2011.3 thousands of persons on the surface of $1468 \mathrm{~km}^{2}$ (Table 1). Katowice is the largest city of the Conurbation and the capital of the province (Figure 1). This is the area with the highest population concentration in Poland. The average population density is 1370.1 persons $/ \mathrm{km}^{2}$.

Table 1. Cities of Upper Silesia Conurbation by number of inhabitants in 2017.

\begin{tabular}{|c|c|c|c|c|}
\hline No. & City & Number of Inhabitants in Thousands & Area in $\mathrm{km}^{2}$ & Density of Population People $/ \mathrm{km}^{2}$ \\
\hline 1 & Katowice & 298.1 & 165 & 1806.7 \\
\hline 2 & Sosnowiec & 205.9 & 91 & 2262.7 \\
\hline 3 & Gliwice & 182.2 & 134 & 1359.7 \\
\hline 5 & Bytom & 169.6 & 69 & 2458.0 \\
\hline 6 & Ruda Śląska & 139.1 & 78 & 1783.3 \\
\hline 7 & Tychy & 128.4 & 82 & 1565.9 \\
\hline 10 & Jaworzno & 92.5 & 153 & 604.8 \\
\hline 11 & Mysłowice & 74.6 & 66 & 1130.3 \\
\hline 12 & Siemianowice Śląskie & 67.9 & 25 & 2716.0 \\
\hline 13 & Tarnowskie Góry & 61.2 & 84 & 728.6 \\
\hline 14 & Będzin & 57.6 & 37 & 1556.8 \\
\hline 15 & Piekary Śląskie & 56.0 & 40 & 1556.8 \\
\hline 19 & Total & 2011.3 & 1468 & 1370.1 \\
\hline
\end{tabular}

Own study based on (2017). 


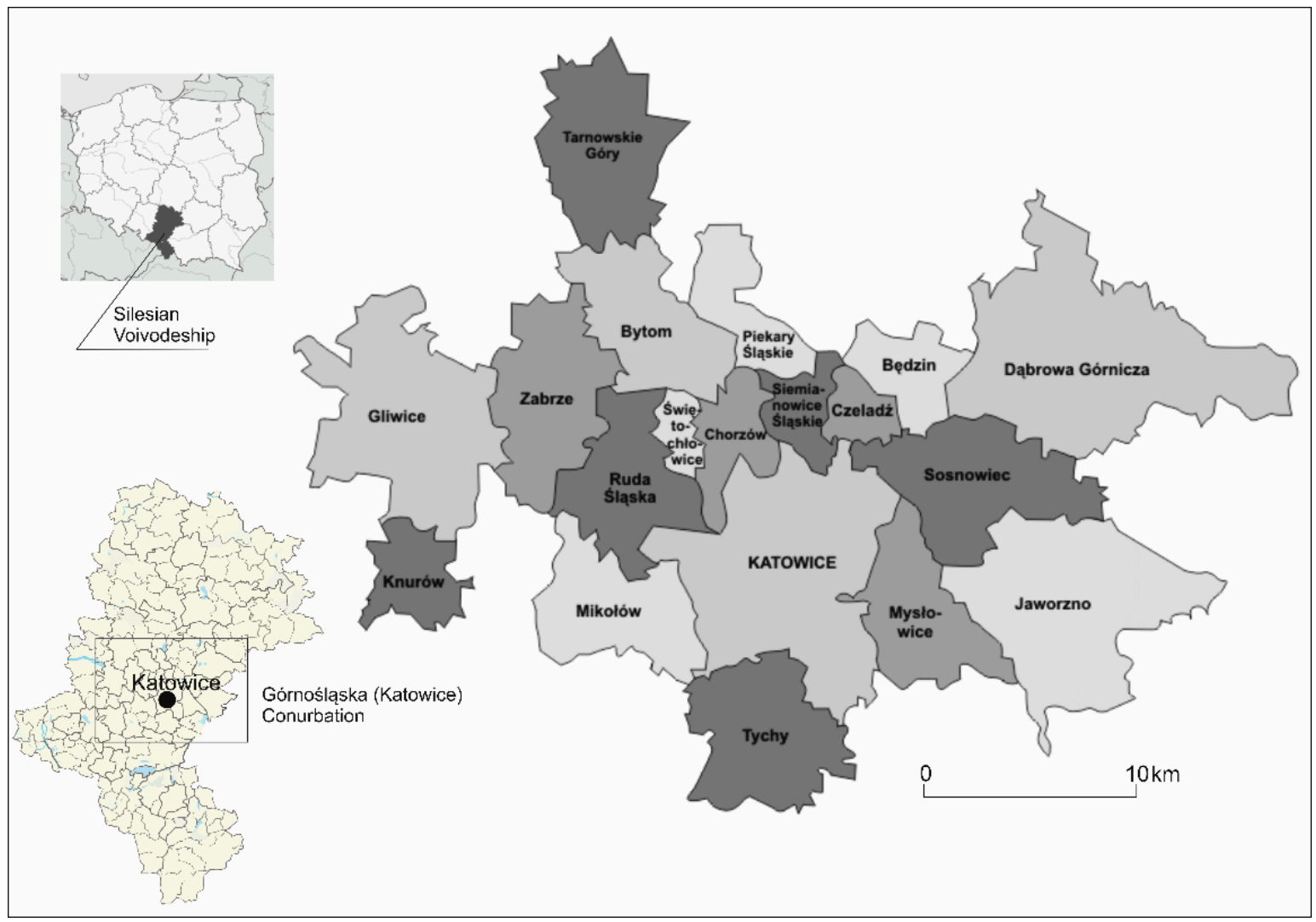

Figure 1. Upper Silesian Conurbation.

On the verge of the economic transformation, in 1989, the GOP was dominated by the extraction industry and the heavy industry. 38 coal mines with 228,200 people employed were operating there, which accounted for $44.8 \%$ of the total employment in the industry. City of Katowice was the largest mining center. 16 ironworks employing 68,000 employees were operating in the same year, which accounted for $13.3 \%$ of people employed in the industry. The largest metallurgical centers were Dabrowa Górnicza, Bytom, Gliwice and Katowice (Tkocz 2015). For over 25 years of the GOP restructuring, the economy of this district underwent profound transformations. In 2012, 35.3\% of all employees were employed in the heavy industry and construction industry, while the share of other sectors, especially services, increased to $64.7 \%$. The production of cars and products for automotive industry, cement, glass, plastics, wood products, food and electrical equipment was developed. IT companies were also created (Tkocz 2015). As the metropolitan functions were developed, the urban landscape has changed; the cultural potential of cities has increased and specialized services of a higher order were provided in the Conurbation (Zuzańska-Żyśko 2016).

New areas with metropolitan features are best shaped in Katowice where urban regeneration projects have been implemented in the former coal mining areas, i.e., Strefa Kultury [the Culture Zone] and the Silesia City Center. The gated communities' settlements typical for metropolises were also created. On a smaller scale, Gliwice, Chorzów and Sosnowiec are also undergoing transformations. Like in Katowice, metropolitan projects for business, administration, culture and science are carried out there. Also, nation-wide cultural institutions have emerged (e.g., orchestras, opera, operetta, theaters, museums, amusement parks), events (e.g., congresses, concerts, festivals, exhibitions, fair, sports events) of international importance as well as sports and recreation facilities (golf courses, water parks, e-sport zone) (Zuzańska-Żyśko 2016).

The growing space of culture, sport and recreation merges with the tourism space, extends it, and makes it more attractive. This is why the cities of the Upper Silesian Conurbation are becoming attractive to a wide range of cultural tourism. Cultural tourism based on the historical, cultural and 
economic heritage of the Upper Silesia and Zagłebie [Coal Basin] is crucial. Undoubtedly, tourist attractions on the Industrial Monuments Route of the Silesian Voivodeship, which are the industrial legacy of the Upper Silesian Conurbation, are of transregional importance. Post-industrial tourism and events such as Industriada, international cyclic conference on industrial heritage tourism in Zabrze combined with the International Trade Fair of Industrial Heritage and Underground Tourism are thriving. Cultural tourism is a significant contribution to changing the image of Upper Silesia Conurbation cities also by exposing the rich history and traditions of the region. Tourists are also attracted by sport events (sports halls Spodek in Katowice and Arena in Gliwice and the Silesian Stadium in Chorzów). The image of the Conurbation is also changed by business tourism (associated with the modern industry and services), congress tourism, event tourism aggregated in Katowice. The image of the Conurbation is also changed by business tourism (associated with the modern industry and services) and congress tourism aggregated in Katowice.

The tourist development in the Upper Silesian Conurbation is further enhanced via the ease of access and transportation in this region and its well-developed tourist infrastructure. Throughout the Conurbation, multinational routes can be found, such as A1 (E-75), and A4 (E-40) highways as well as railway routes: Wrocław-Katowice-Kraków-Przemyśl, Katowice-Warszawa-Gdańsk and Katowice-Wrocław-Szczecin. Air link is provided by the airport Katowice-Pyrzowice. The hotels' capabilities meet the demand for accommodation. A constant increase in the numbers of hotels can be observed in the cities within the Conurbation-the highest in Katowice, whilst the older hotels are modernized. The majority of the hotels are three- or four-stars standard. However, hotels of a very high standard (five stars) remain few.

\section{Actions and Concepts of Changing the Negative, Stereotypical Perception of the Upper Silesian Conurbation Cities}

Unambiguous associations with the heavy industry and degraded natural environment and pollution were perceived as a serious problem blocking the socio-economic development of the region for many years. In 1997, a local government reform was carried out in Poland, which also introduced new subdivisions of the country. The Silesian Voivodeship with the capital in Katowice was established, strong local governments were established at the level of the voivodeship and particular cities and communes. This was also when the problem of industrial associations with the name 'Silesia' was so strongly voiced in the public debate for the first time. Popular tourist destinations in the Silesian Beskids Mountains and the Kraków-Częstochowa Upland became parts of the newly created voivodeship. From the very beginning, representatives of these regions expressed their concerns that the 'Ślaskie' name of the voivodeship would be a factor that would hamper attracting domestic tourists. Therefore, it is not surprising that the first plans for actions to refresh the image of Silesia (more precisely: of the Upper Silesia) are parts of the strategies developed by the authorities of the entire voivodeship, especially by those involved in the development of tourism. In subsequent years, similar plans were also created in the self-governments of the individual cities of the Conurbation, as the Conurbation as a whole is not subject in terms of the country subdivision and there are no local government authorities or other bodies that represent it. In general, two complementary directions to refresh the industrial image of the Conurbation cities can be distinguished in these planned (and already partly implemented) actions. The first is based on a partial detachment from industrial roots and on creating new associations. The Katowice authorities are particularly active in this field. The second direction is using the industrial heritage of the region to build positive associations. This direction can be clearly seen in the actions of the voivodeship authorities and the Regional Tourist Organization (Silesian Tourist Organization) that cooperates with them.

Strategia Promocji Katowic (Katowice Promotion Strategy) [The Katowice Promotion Strategy] adopted in 2012, basically does not address the subject of industrial history and heritage as an element of promotion and creation of a new brand of the city. The authors of the strategy pointed out the need to find the widest possible and inclusive range of unique factors/complementary features that, 
when aggregated, will create a new, desired image of Katowice (Strategia Promocji Katowic Katowice Promotion Strategy, p. 146). According to the strategy, a multidimensional transformation is to be the main feature of the new image of the city, with five features as its components that will ultimately be a prism to view Katowice. These features are: metropolitanism, heritage, alternative, activity and eco-responsibility; at the same time the first two features have been at least part of the city image before, while the other three features were to become new components of Katowice's promotion. (Strategia Promocji Katowic Katowice Promotion Strategy, pp. 148-49). The process described resulted in the use of numerous signs and slogans to promote Katowice. Signs and slogans of heterogeneous stylistics, different colors and diverse purposes were also often used.

The current promotional messages of the city are dominated by two messages related to the unquestionable successes of the city authorities and adhering to the assumptions presented above. The first one of them is promotion of the city as a meeting place based on the image of one of the largest and most modern congress centers in Poland (Międzynarodowe Centrum Kongresowe [International Congress Center]), which is a host of numerous events of international significance. The second course of actions of the city's promotional activities is the use of the UNESCO's Creative City in music title obtained in 2015. The Silesian Voivodeship is the first region in Poland that took on the task of creating a tourist promotion strategy as well as investment and economic promotion strategy, which means building a coherent brand of the region. According to the diagnosis made for the purposes of the Marketing Communication Strategy of the Silesian Voivodeship (2014), the image is the weakest side of the 'Ślaskie' [Silesian] brand and it required immediate and thoroughly considered communication actions, because the image of the voivodeship was much worse than the voivodeship condition actually was in reality, while the biggest difference between the real and emotional dimension can be seen in the tourist offer (Strategia Komunikacji Marketingowej Województwa Śląskiego Silesian Voivodeship Marketing Comminication Strategy).

At the level of communication and creation, the 'Ślaskie' brand definition was based on the so-called big idea, which reads 'Śląskie. Pozytywna Energia' [Silesian. Positive Energy]. 'Positive Energy' is supposed to be a universal message that will function as a bracket that combines various branches of activity, cities and subregions. Interpretations of this phrase are diverse ('energy infects', 'spiritual energy, 'energy of wild nature', 'full of energy'), depending on the situation and context, taking the right form. However, it is always supposed to mean that 'thanks to its diversity, Silesia is a region full of energy' and to evoke linguistically resonant associations such as 'creative, dynamic, effective, optimistic' (www.slaskie.pl). The identity of the voivodeship suggested in the strategy clearly breaks away from industrial roots and associations, which is natural, the more so if you consider that industrial conurbation cities are only a part of the voivodeship and their negative stereotype was perceived as a threat to the development of the entire region.

Being part of the Voivodeship Development Strategy (2013) and the Marketing Communication Strategy (2014), the Tourism Development Strategy in the Silesian Voivodeship 2020+ 2017 (2017) indicates that the target image of tourism development in the voivodeship is: 'The Silesian Voivodeship is a region full of positive energy, where tourism is one of the important sectors of the economy, which develops taking into account the principles of sustainable development using the richness and diversity of natural and cultural assets, in particular the post-industrial heritage, which gives tourists, both domestic and foreign, and residents of the region the opportunity to relax, as well as for active and attractive leisure activities throughout the year.' (Tourism Development Strategy in the Silesian Voivodeship 2020+2017, p. 61) It can be seen that in this case there is a clear reference to the industrial heritage of the region, which is to be perceived as a serious asset rather than as weak point of the region on the tourist market. Creation, constant development and promotion of the Industrial Monuments Route of the Silesian Voivodeship, which is the oldest and largest route of this kind in the country, is one of the components of the implementation of this Strategy, as well as of the previous one. The Industrial Monuments Route is a subject-related, road tourist and cultural route that connects the industrial heritage culture sites of the Silesian Voivodeship. At present, it consists of 42 locations. It includes 
sites located in the Conurbation area as well as in other areas that belong to the Silesian Voivodeship. The voivodeship authorities are heavily involved in the development of the route; the Industrial Monuments Route is a multi-award-winning project. In 2008, it was awarded the Gold Certificate of the Polish Tourist Organization for the best tourist product in the country (www.zabytkitechniki.pl).

\section{Attempts to Identify the Image of the Upper Silesian Conurbation}

So far, most of the subject of research was the image of the voivodeship as a whole (Millward-Brown SMG/KRC 2010; ARC Rynek i Opinia 2014; TNS Polska 2014; Hendel and Żemła 2015), which may be the result of, among others, the way how tourism in Poland is spatially organized and of particular activity of regional tourist organizations, including the Silesian Tourist Organization, whereas the way the Conurbation is perceived has not been commonly analyzed in detail. The results of those studies are usually a bit ambiguous and reflect the fact that the Silesian voivodeship consists of differentiated areas such as; the Upper Silesian Conurbation, a popular mountain resorts, Kraków-Częstochowa Upland being very attractive for tourists; and Czestochowa, the most important pilgrimage place in Poland. It is not surprising that interviewees asked about their associations connected with such a region were also giving differentiated answers, however, those connected with industry were among the most popular (Millward-Brown SMG/KRC 2010; ARC Rynek i Opinia 2014; TNS Polska 2014; Hendel and Żemła 2015). Szubert and Żemła (2019) recently presented their results of studies dedicated particularly to the image of the Upper Silesian Conurbation carried out with students from Kraków which means that the sample consisted of interviewees who lived relatively close to the area analyzed (Katowice and Kraków are in distance of less than $100 \mathrm{~km}$ to each other, the cities are connected by a highway). Characteristic is the fact that as many as $76 \%$ of interviewees indicated associations related to the extraction industry when asked about their associations with the Conurbation in open-ended question. Most of these answers were: coal, mines, industrial district, extraction, heavy industry, steelworks. Very similar conclusions can be drawn from further results presented in the cited paper. The only answer (out of the list of 19 potential associations) selected by over half of the interviewees $(62 \%)$ was 'dominated by industry', followed by another unambiguously negative associations related to the industrial character of the area: 'made of concrete' $(46 \%)$ and 'dirty' (38\%). Although as many as 31\% of the interviewees noticed that the Conurbation and its individual cities are also changing, very few people noticed the positive effect of these changes. Associations related to promotional slogans, which were quoted previously, were indicated at most $12 \%$ ('full of energy' and 'creative'), and in most cases it was even less than $10 \%$, while the green character of this area was hardly ever noticed by anyone. In place of this, the most negative associations from the point of view of the ability to attract the potential tourists, 'uninteresting' and 'boring', were indicated by about 20\% (Szubert and Żemła 2019).

\section{Geographical Education in Poland}

The image of a location is a conglomerate composed of feelings, judgments, opinions, attitudes and facts. The image of a location understood in this way is shaped by a dynamic process throughout a person's whole life. It may change as a result of learning a region or a location by one's own experience or indirectly through the reception of various information about it. This process can be ordered or random, chaotic. In the first case, it takes place in school, at different levels of education, especially geographical education. In the second case, the image of a location is shaped by spot-checking observations while visiting a given location, by accidentally received or media reports limited to a few instances or subjective opinions of other people, not always certified by up-to-date knowledge about the place being discussed. Thus, the image of a location can be coherent and consistent with reality or inconsistent with it, based on stereotypes or outdated knowledge.

Geographical education plays an extremely important role in shaping the image of a location. Therefore, the fact that the way tourist destinations are presented in geographic textbooks and its impact on the image of these destinations has not been the subject of in-depth scientific research so far, is surprising. As the researchers analyzed autonomous sources of information, they were focused 
mainly on the analysis of media reports (Rodríguez Campo et al. 2011; Wang et al. 2015; Kim et al. 2017) television series (Fu et al. 2016) and the social media (especially the Trip Advisor portal) (Ghazali and Cai 2014; Kladou and Mavragani 2015; Sun et al. 2015; Tamajón and Valiente 2017). It should be emphasized that analyses of the content of geographic textbooks is also restricted by a number of important factors. First of all, the point is the fact that geography school education is diversified across individual countries and adapted to local conditions and educational needs of these countries, and what is always presented in a particularly detailed way is just the geography of each home country. Therefore, the analysis of the content of geographic textbooks is particularly useful for destinations where a significant part of tourism is domestic tourism. The Upper Silesia Conurbation is precisely an example of such a region.

The most important document that defines the course, goals and curriculum in Poland is the core curriculum of general education approved by the Minister of National Education. Study group students started their geographic education in middle school/junior high school [Polish: gimnazjum] and it lasted three years. At this stage of education, the geographical education about Poland was most extensive.

In the interaction that occurs between the student and teacher, a significant role is played by the textbook. Its contents require being supplemented or updated by a teacher who can be creative in his/her approach when teaching about geographical regions of Poland by presenting new trends in the development of regions based on deliberate selection of the textbook's content. Textbook and geography lesson are the basic sources of information for students both in middle schools/junior high schools (12-13 years, 15-16 years) and high schools (17-18 years). This is confirmed by research carried out in eight countries (Germany, Poland, Slovenia, Greece, Sweden, Cyprus, Ireland, France) with a population of 2080 students. The vast majority (79.0\%) indicated that geography lessons and textbooks for this subject provide them with the best knowledge about Europe (Piróg 2013; Resnik-Planinc 2013).

The school textbook market in Poland is a commercial market. There are many competing publishing houses, and the market leaders are: Nowa Era and Wydawnictwa Szkolne i Pedagogiczne. Other significant publishers are: Wydawnictwo Edukacyjne Wiking, Wydawnictwo Szkolne Polskiego Wydawnictwa Naukowego and Wydawnictwo Pedagogiczne Operon. These are nationwide publishing houses. There are also other publishing houses operating on a regional scale, e.g., Stowarzyszenie Oświatowców Polskich, Oficyna Wydawnicza Turpres. In practice, this means that there are many geography textbooks by different authors on the market. The content of all textbooks must be in line with the core curriculum for a given stage of general education. This is the basis for the textbook's approval to be used for school use by the Minister of National Education. They are different in terms of their publishing concept (including graphics) and the substantive presentation of topics, because it is the author of the textbook who decides it. The most popular textbooks for Polish geography for grade 2 and 3 in the middle school/junior high school were analyzed in detail (Table 2). It should be emphasized that the study covered all textbooks of the most popular pedagogical publishing houses in Poland. 
Table 2. Selected geography textbooks for middle schools/junior high schools.

\begin{tabular}{|c|c|c|c|}
\hline Textbook Marking & Author & Title & Publishing House \\
\hline 1 & M. Szubert & $\begin{array}{l}\text { Planeta Nowa } \\
\text { Podręcznik do geografii dla klasy trzeciej } \\
\text { gimnazjum [Planet New. Textbooks for } \\
\text { Geography for the Third Grade of Middle } \\
\text { School/Junior High School] }\end{array}$ & Nowa Era \\
\hline 2 & R. Malarz & $\begin{array}{l}\text { Puls Ziemi } 3 \\
\text { Podręcznik do geografii dla gimnazjum [Earth } \\
\text { Pulse 3. Textbooks for Geography for Middle } \\
\text { School/Junior High School] }\end{array}$ & Nowa Era \\
\hline 3 & F. Szlajfer & $\begin{array}{l}\text { Geografia dla gimnazjum. Moduł 2: geografia } \\
\text { Of Poland [Geography for Middle } \\
\text { School/Junior High School. Module 2: } \\
\text { Geography of Poland] }\end{array}$ & Nowa Era \\
\hline 4 & $\begin{array}{l}\text { A. Lechowicz } \\
\text { M. Lechowicz } \\
\text { P. Stankiewicz } \\
\text { E. Sulejczak }\end{array}$ & $\begin{array}{l}\text { Bliżej geografii. Podręcznik. Część } 2 . \\
\text { Gimnazjum [Closer to Geography. Textbook. } \\
\text { Part 2. Middle School/Junior High School] }\end{array}$ & $\begin{array}{l}\text { Wydawnictwa Szkolne i } \\
\text { Pedagogiczne }\end{array}$ \\
\hline 5 & $\begin{array}{l}\text { T. Majchrzak } \\
\text { P. Wład }\end{array}$ & $\begin{array}{l}\text { Nowa nasza planeta } \\
\text { Geografia } 3 \\
\text { podreccznik dla gimnazjum [New Our Planet } \\
\text { Geography } 3 \\
\text { Textbook for Middle School/Junior High } \\
\text { School] }\end{array}$ & $\begin{array}{l}\text { Wydawnictwo Szkolne } \\
\text { Polskiego Wydawnictwa } \\
\text { Naukowego }\end{array}$ \\
\hline 6 & $\begin{array}{l}\text { E. Dudek } \\
\text { J. Wójcik }\end{array}$ & $\begin{array}{l}\text { Geografia bez tajemnic Polska i jej sasiedzi } \\
\text { Podrecznik dla klasy drugiej gimnazjum } \\
\text { [Geography Without Secrets. Poland and its } \\
\text { Neighbors } \\
\text { Textbook for the Second Grade of Middle } \\
\text { School/Junior High School] }\end{array}$ & $\begin{array}{l}\text { Wydawnictwa } \\
\text { Edukacyjne Wiking }\end{array}$ \\
\hline 7 & $\begin{array}{l}\text { T. } \\
\text { Krynicka-Tarnacka } \\
\text { G. Wnuk } \\
\text { Z. Wojtkowicz }\end{array}$ & $\begin{array}{l}\text { Ziemia i ludzie. Geografia } 2 \\
\text { - } \quad \text { podręcznik [Earth and People. Geography } 2 \\
\text { - } \quad \text { Textbook] }\end{array}$ & $\begin{array}{l}\text { Stowarzyszenie } \\
\text { Oświatowców Polskich } \\
\text { Toruń }\end{array}$ \\
\hline 8 & $\begin{array}{l}\text { M. Kluba } \\
\text { E. Światlski } \\
\text { P. Świtalski }\end{array}$ & $\begin{array}{l}\text { Polska } \\
\text { Podrecznik geografii dla III klasy gimnazjum } \\
\text { [Poland } \\
\text { Textbooks for Geography for the Third Grade } \\
\text { of Middle School/Junior High School] }\end{array}$ & $\begin{array}{l}\text { Oficyna Wydawnicza } \\
\text { Turpres }\end{array}$ \\
\hline 9 & $\begin{array}{l}\text { G. Chmielewska } \\
\text { W. Chmielewski }\end{array}$ & $\begin{array}{l}\text { Geografia } \\
\text { Podrecznik dla } 3 \text { klasy gimnazjum. } \\
\text { [Geography Textbooks for the Third Grade of } \\
\text { Middle School/Junior High School] }\end{array}$ & $\begin{array}{l}\text { Wydawnictwo Szkolne } \\
\text { Operon }\end{array}$ \\
\hline
\end{tabular}

Source: own elaboration.

The analyzed textbooks were elaborated in the period between 2009-2010 and remained mandatory in schools in their original form in years 2011-2019. The contents concluded, related to the Upper Silesia's conurbation should include the changes that have occurred within the 20 years of economic transformation (since 1989) shown in Chapter 3. Primarily, the increase of the economical meaning of service should be the subject of concern, as well as the structural changes in industry, the reduction of mining and iron metallurgy's participation in production and the increase of production related to the use of modern technology. During the edition of the analyzed manuals some changes to the cultural landscape took place. Urban cultural space was evolving, and cultural tourism with it.

\section{Upper Silesian Conurbation in Geography Textbooks for Middle School/Junior High School}

Description of Upper Silesia Conurbation in textbooks is contained in the following chapters: the natural environment of Poland, population and urbanization, Polish economy (industry) and the 
description of Polish Uplands (Table 3). The synthetic characteristics of the Upper Silesian Conurbation is related to the description of the Silesian Upland, the geographical region of Poland where it is located, while the detailed issues that make up the image of this region can be found in individual parts of textbooks.

Table 3. Detailed analysis of the content distribution describing the Upper Silesian Conurbation in selected textbooks.

\begin{tabular}{|c|c|}
\hline \multirow{5}{*}{1} & Textbook Marking \\
\hline & $\begin{array}{l}\text { Rocks and Mineral Resources } \\
\text { Distribution of Mineral Resources }\end{array}$ \\
\hline & $\begin{array}{l}\text { Population and Urbanization } \\
\text { Urbanization } \\
\text { Types of Urbanization }\end{array}$ \\
\hline & $\begin{array}{l}\text { Agriculture and Industry } \\
\text { Transformations in Polish Industry } \\
\text { Industrial Districts in Poland } \\
\text { Mining } \\
\text { Energetics }\end{array}$ \\
\hline & $\begin{array}{l}\text { Polish Uplands } \\
\text { Silesian-Krakow Upland } \\
\text { Upper Silesian Industrial District }\end{array}$ \\
\hline \multirow[b]{3}{*}{2} & $\begin{array}{l}\text { Characteristics of Polish Geophysical Regions } \\
\text { Uplands } \\
\text { Silesian Upland }\end{array}$ \\
\hline & $\begin{array}{l}\text { Area, Population and Urbanization in Europe and in Poland } \\
\text { Urbanization in Poland }\end{array}$ \\
\hline & $\begin{array}{l}\text { Industry in Europe and in Poland } \\
\text { Extraction Industry in Poland } \\
\text { Energy Resources } \\
\text { Distribution and Extraction of Mineral Resources } \\
\text { Upper Silesian Coal Basin } \\
\text { Energy Industry in Poland } \\
\text { The Largest Power Plants in Poland } \\
\text { Processing Industry and Industrial Districts in Poland } \\
\text { Metallurgical Industry } \\
\text { Industrial Districts in Poland } \\
\text { Upper Silesian Industrial District }\end{array}$ \\
\hline \multirow{3}{*}{3} & $\begin{array}{l}\text { Population of Poland } \\
\text { Internal Migrations and Urbanization } \\
\text { Upper Silesian Agglomeration }\end{array}$ \\
\hline & $\begin{array}{l}\text { Industry } \\
\text { Extraction Industry (mining) } \\
\text { Metallurgical Industry } \\
\text { Diversity of the Level of Industrialization in Poland, Industrial Districts }\end{array}$ \\
\hline & $\begin{array}{l}\text { Uplands } \\
\text { Division of Uplands } \\
\text { Silesian Upland }\end{array}$ \\
\hline
\end{tabular}


Table 3. Cont.

From the Baltic Sea to the Peaks of the Tatras

Geographical Regions

Diversity of the Landscape within the Upland

Silesian Upland

\section{Population of Poland}

Diversity of Population

The Largest Density of Population (in the Silesian Voivodeship)

Expansion of Settlement on the Territory of Poland

Polish Cities and Villages

City with the Highest Population Density (Świętochłowice).

Selected Ethnographic Groups in Poland

Silesians

\section{Images from the Geological Past of the Present-Day Poland}

Mineral Raw Materials are the Wealth of Poland

Coal, Upper Silesian Basin

Population and Settlement in Poland

The Urbanization Process and the Expansion of Large Urban Complexes

Upper Silesian Conurbation

5 Problems of the Polish Economy

Traditional or Alternative-How We Use Energy Sources

Thermal Power Stations

Problems of Expansion and Concentration of Industry in Poland

Upper Silesian Industrial District

From the Baltic Sea to the Carpathians

Assets and Economic Barriers of the Polish Uplands

Silesian Upland

Upper Silesian Industrial District

Industrial Monuments Route of the Silesian Voivodeship

\section{Environment}

Mineral Raw Materials

Energy Raw Materials

\section{Regional Overview}

Diversity of the Natural Environment in the Polish Uplands

6

Silesian Upland

\section{Economy}

Changes in Population Distribution. Urbanization Processes

Settlement and Protection of the Natural Environment

Electric Power Industry and Its Role in the Polish Economy

Industrial Districts. Contemporary Problems of Industry in Poland

The Silesian-Kraków District

Location and Geographical Environment of Poland

Energy Raw Materials, Coal

Population and Economy

Polycentric Agglomeration (Conurbation)

\section{Industry}

Use of Non-Renewable Energy Sources

Fuel and Energy Industry

Geographic Regions of Poland

Silesian Upland

Upper Silesian Industrial District 
Table 3. Cont.

\begin{tabular}{|c|c|}
\hline \multirow{3}{*}{8} & $\begin{array}{l}\text { Features of the Territory of The Geographical Environment of Poland in Relation to } \\
\text { Other Countries } \\
\text { Mineral Raw Materials }\end{array}$ \\
\hline & $\begin{array}{l}\text { Activity of the Society in the Geographical Environment of Poland in Relation to Other } \\
\text { Countries } \\
\text { Industry in Poland in Relation to Other Countries } \\
\text { Upper Silesian Industrial District }\end{array}$ \\
\hline & $\begin{array}{l}\text { My Little Homeland } \\
\text { Polish Uplands } \\
\text { Silesian Upland }\end{array}$ \\
\hline \multirow{5}{*}{9} & $\begin{array}{l}\text { Natural Environment } \\
\text { Types and Significance of Rocks in Poland }\end{array}$ \\
\hline & $\begin{array}{l}\text { Population of Poland } \\
\text { Cities are changing } \\
\text { Urbanization }\end{array}$ \\
\hline & $\begin{array}{l}\text { Economic Geography of Poland } \\
\text { Industry-Mineral Raw Materials } \\
\text { Energy Raw Materials } \\
\text { Energy Industry } \\
\text { Energy Obtained from Coal Combustion } \\
\text { Industrial Processing } \\
\text { Metallurgy } \\
\text { Electrical Machinery Industry }\end{array}$ \\
\hline & $\begin{array}{l}\text { Transport and Communication } \\
\text { Air Transport }\end{array}$ \\
\hline & $\begin{array}{l}\text { Geographic Regions of Poland } \\
\text { Silesian Upland }\end{array}$ \\
\hline
\end{tabular}

The analysis of the manuals' content has been based on three criteria: thematic, substantive and key words. Based on the thematic criterion, the subjects of the lectures, which contents are related to the Upper Silesia's Conurbation, have been extracted. The substantive criterion served as the basis for defining the range of the characteristics and extracting sets of key words related to e.g., natural conditions, economy, society, cultural landscape and tourism. Next, the occurrence of the key words has been thoroughly studied in the analyzed manuals. An additional criterion for the manuals' analysis was the graphical layout related to the Upper Silesia's conurbation.

In the textbooks analyzed, different terminology is used. In addition to the correct name, i.e., Upper Silesia Conurbation, the following names are used: the Upper Silesian agglomeration, the Urban Complex of the Upper Silesian Industrial District or, when writing about cities located on the Silesian Upland, the proper name is omitted.

Upper Silesian Conurbation is presented as an example of a polycentric agglomeration that consists of a dozen or so cities (occasionally their number is specified-19); none of them dominates over the others. Several of them, the biggest ones, are sometimes specified: Katowice, Sosnowiec, Gliwice, Zabrze, and Bytom. Generalized maps of the Conurbation that show generalized shapes of urban areas were included only in several textbooks, while by means of circular signatures-their size expressed by the volume of population was shown. An important feature of the Conurbation, i.e., a network of road and rail connections connecting the Conurbation cities was also exposed.

Fuel and energy industry, metallurgy and industrial processing were indicated in the characteristics of the economy of the Conurbation cities (in chapters related to industry). The maps show the Upper Silesian Industrial District and the largest industrial centers: Katowice, Bytom, Chorzów, Sosnowiec 
(Table 3). In chapters related to the natural environment of Poland, the Conurbation is connected with hard coal deposits, i.e., with the Upper Silesian Basin. The characteristics of the Conurbation in the textbooks analyzed is different in terms of how many details are present. In all textbooks, the description applies to the entire area, not to individual cities. The origin and expansion of the Conurbation are associated with the expansion of industry, especially hard coal mining as well as iron and steel industry in the area of the Silesian Upland and with establishing the Upper Silesian Industrial District (Table 4). The characteristics of the economy of this area begin with the exposure of the dominant share of the fuel and energy industry, i.e., with the aforementioned hard coal mining and thermal energy based on this fuel. This thread is additionally amplified by photographs of mine shafts and power plants. Subsequently, iron metallurgy, production of machinery and equipment (mainly for mining) and car production are mentioned. The car factories in Tychy and Gliwice are examples of new trends in the expansion of the Upper Silesian industry in connection with its restructuring. Degradation and transformation of the natural environment associated with the strong industrialization of the area is also emphasized. Air and surface water pollution is stressed. In some textbooks, photos of mine heaps are presented.

A strong accent on the role of traditional industry, i.e. coal mining, makes information about industrial restructuring hard to see. It is mainly about the economic problems of mining: declining profitability of mines and mines being shut down. Too little attention has been devoted to modern factories that are built in the Katowice Economic Zone, where, in addition to car production, the production of electrical and electronic equipment, chemical products and food is also expanding. Brief descriptions are made as comments on photographs that show the production of cars.

Important areas of contemporary socio-economic development of Conurbation cities, such as the development of services, higher education as well as science and culture have not even been raised in any of the textbooks discussed. References to other topics, such as sports, recreational and green areas, and rehabilitation of degraded areas were made in just one of nine textbooks. The same applies to the Industrial Monuments Route advertised by the local government authorities of the region as a new showcase of the entire voivodeship. In one of the textbooks, a photograph of 'Spodek' is presented, which is a sports and entertainment arena in Katowice. This is the most easily recognizable building in the Conurbation and unambiguously associated with Katowice (Table 5). In one of the textbooks, a plan of the largest recreation area in the Conurbation, i.e., the Silesian Park was also presented. This park (about 500 ha) was established in the 1950s in post-mining areas, in the center of the Conurbation, between Katowice, Chorzów and Siemianowice Ślaskie. It includes recreational facilities and equipment, the Silesian Stadium, the Silesian Planetarium and the Silesian Zoological Garden. 
Table 4. The most important features of the Upper Silesian Conurbation based on middle school/junior high school geography textbooks.

\begin{tabular}{|c|c|c|c|c|c|c|}
\hline \multirow{2}{*}{ Component of the Conurbation Description } & \multicolumn{6}{|c|}{ Textbook Marking (Table 2.) } \\
\hline & 1 & 4 & 6 & 7 & 8 & 9 \\
\hline \multicolumn{7}{|l|}{ Upper Silesian Industrial District } \\
\hline \multicolumn{7}{|l|}{ The Most Industrialized Area of Poland } \\
\hline \multicolumn{7}{|l|}{ The Most Populated Area of Poland } \\
\hline \multicolumn{7}{|l|}{ One of the Most Urbanized Areas of Poland } \\
\hline \multicolumn{7}{|l|}{ Coal Deposits } \\
\hline \multicolumn{7}{|l|}{ Coal Basin } \\
\hline \multicolumn{7}{|l|}{ Deposits of Zinc and Lead Ores } \\
\hline \multicolumn{7}{|l|}{ Coal Mines } \\
\hline \multicolumn{7}{|l|}{ Iron Metallurgy } \\
\hline \multicolumn{7}{|l|}{ Zinc and Lead Metallurgy } \\
\hline \multicolumn{7}{|l|}{ Coking Plants } \\
\hline \multicolumn{7}{|l|}{ Machine Production } \\
\hline \multicolumn{7}{|l|}{ Thermal Energetics } \\
\hline \multicolumn{7}{|l|}{ Industrial Restructuring } \\
\hline \multicolumn{7}{|l|}{ Shutdown of Mines and Steelworks } \\
\hline \multicolumn{7}{|l|}{ Modern Industry } \\
\hline \multicolumn{7}{|l|}{ E.g., Car Production } \\
\hline \multicolumn{7}{|l|}{ Communication Networks } \\
\hline \multicolumn{7}{|l|}{ Road, Railway } \\
\hline \multicolumn{7}{|l|}{ Natural Landscape Degradation, } \\
\hline \multicolumn{7}{|l|}{ Mining Damage, Heaps } \\
\hline \multicolumn{7}{|l|}{ Air Pollution, Water Pollution } \\
\hline \multicolumn{7}{|l|}{ Ecological Disaster Area } \\
\hline \multicolumn{7}{|l|}{ Recultivation of Post-Industrial Areas } \\
\hline \multicolumn{7}{|l|}{ Green Areas } \\
\hline (Recreational Areas, Sports Areas) & & & & & & \\
\hline Development of Services & & & & & & \\
\hline Higher Education, Science & & & & & & \\
\hline Cultural Institutions & & & & & & \\
\hline (E.g., Museums, Theaters, etc.) & & & & & & \\
\hline Ethnographic Groups-Silesians & & & & & & \\
\hline Sport, Sports Facilities & & & & & & \\
\hline Tourism & & & & & & \\
\hline E.g., Industrial Monuments Route of the Silesian & & & & & & \\
\hline Voivodeship & & & & & & \\
\hline
\end{tabular}

Source: own elaboration.

Table 5. The detailed analysis of illustrations related to the Upper Silesian Conurbation in selected textbooks.

\begin{tabular}{lll}
\hline TextbookMarking & Photograph/Figure & Description \\
\hline & $\begin{array}{l}\text { Map } \\
\text { Distribution of Mineral Raw Materials }\end{array}$ & Coal, Katowice. \\
\cline { 2 - 3 } $\begin{array}{l}\text { Map } \\
\text { Arrangement and Size of the City }\end{array}$ & Cities of the Conurbation, Katowice. \\
\cline { 2 - 2 } $\begin{array}{l}\text { Map } \\
\text { Types of Agglomeration }\end{array}$ & Polycentric agglomeration cities \\
\hline $\begin{array}{l}\text { Map } \\
\text { Industrial Districts in Poland }\end{array}$ & $\begin{array}{l}\text { The Silesian-Kraków District. } \\
\text { Branches of industry: mineral, automotive, metallurgical, metal and machinery, } \\
\text { fuel and energy, chemical, food. }\end{array}$ \\
\cline { 2 - 3 } & $\begin{array}{l}\text { Photograph } \\
\text { Car Assembly Line }\end{array}$ & $\begin{array}{l}\text { Opel's car factory in Gliwice is the largest foreign investment in the Katowice } \\
\text { special economic zone. }\end{array}$ \\
\hline $\begin{array}{l}\text { Photograph } \\
\text { Heap }\end{array}$ & $\begin{array}{l}\text { Mine and steelworks post-production waste heaps are the characteristic feature } \\
\text { in the Silesian Landscape. }\end{array}$ \\
\hline
\end{tabular}


Table 5. Cont.

\begin{tabular}{|c|c|c|}
\hline TextbookMarking & Photograph/Figure & Description \\
\hline & $\begin{array}{l}\text { Photograph } \\
\text { Silesian Stadium * }\end{array}$ & $\begin{array}{l}\text { Mecca for Polish Football } \\
\text { The inhabitants of the Silesian Upland are great fans of sports, especially of } \\
\text { football. It is at the Upper Silesia Conurbation in Chorzów that the Silesian } \\
\text { Stadium (also called the 'national') is located. It can accommodate over } 47,000 \\
\text { viewers and is the second facility of this kind in Poland. It is here that the } \\
\text { representation of Poland played over } 50 \text { matches, including the legendary } \\
\text { ones: with the USSR in 1957, won by Poles 2: 1, and with England in } 1973 \text { (2: } \\
\text { 0). In 1960, the Silesia Stadium hosted 'King of Football'-the Brazilian Pelé } \\
\text { with FC Santos team. }\end{array}$ \\
\hline \multirow{4}{*}{2} & $\begin{array}{l}\text { Map } \\
\text { Distribution and Extraction of Mineral Raw } \\
\text { Materials }\end{array}$ & Coal, Katowice. \\
\hline & $\begin{array}{l}\text { Figure } \\
\text { Formation of Coal }\end{array}$ & $\begin{array}{l}\text { Four stages of coal formation. } \\
\text { Coal is a sedimentary rock of organic origin. It was formed from plant debris in a } \\
\text { hot and humid climate inside the depressions of the area. Coal deposits that } \\
\text { occur in Poland were formed during the Carboniferous Era. }\end{array}$ \\
\hline & $\begin{array}{l}\text { Map } \\
\text { Types of Agglomeration }\end{array}$ & Polycentric agglomeration cities. \\
\hline & $\begin{array}{l}\text { Photograph } \\
\text { Car Assembly Line }\end{array}$ & Every year, over 200.000 new cars are produced in the Tychy factory. \\
\hline \multirow{11}{*}{3} & \multirow{2}{*}{$\begin{array}{l}\text { Photographs } \\
\text { Coal Mine }\end{array}$} & $\begin{array}{l}\text { Jas-Mos coal mines (former KWK Jastrzẹbie) owned by Jastrzębska Spółka } \\
\text { Węglowa, established as part of the mining restructuring in Upper Silesia. }\end{array}$ \\
\hline & & 'Klimontów' 19th century coal mine in Sosnowiec. \\
\hline & $\begin{array}{l}\text { Figure } \\
\text { Steelworks (Historical View) }\end{array}$ & $\begin{array}{l}\text { Kings Steelworks in Chorzów from the beginning of the 19th century } \\
\text { (Lithography). }\end{array}$ \\
\hline & $\begin{array}{l}\text { Map } \\
\text { Industrial Districts of Poland }\end{array}$ & Upper Silesian Industrial District. \\
\hline & $\begin{array}{l}\text { Photograph } \\
\text { Katowice-Kraków Highway }\end{array}$ & Jaworzno Junction. In the background, the Jaworzno III power plant is seen. \\
\hline & $\begin{array}{l}\text { Map } \\
\text { Quantity of Passengers Served by the } \\
\text { Largest Polish Airports }\end{array}$ & Katowice. \\
\hline & $\begin{array}{l}\text { Photograph } \\
\text { Silesian Upland-Area of the Largest } \\
\text { Ecological Disaster in Poland }{ }^{* *}\end{array}$ & $\begin{array}{l}\text { Industrial landscape. } \\
\text { Heavily degraded area. }\end{array}$ \\
\hline & $\begin{array}{l}\text { Economic Map } \\
\text { of the Silesian Upland }\end{array}$ & $\begin{array}{l}\text { Extraction industry: coal, zinc and lead ores; processing industry: thermal power } \\
\text { plants, iron industry, machine industry, automotive industry, coke industry, } \\
\text { chemical industry. }\end{array}$ \\
\hline & $\begin{array}{l}\text { Photograph } \\
\text { Industrial Landscape of the Silesian Upland }\end{array}$ & Thermal power plant, cooling towers, chimneys. \\
\hline & $\begin{array}{l}\text { Map } \\
\text { Solid Industrial Waste }\end{array}$ & Volume of industrial waste produced in the Upper Silesian Agglomeration. \\
\hline & $\begin{array}{l}\text { Photograph } \\
\text { Most of the Coal from the Upper Silesian } \\
\text { Industrial District is Transported by } \\
\text { Railway. }\end{array}$ & Freight trains in the marshalling yard. \\
\hline 4 & $\begin{array}{l}\text { Photograph } \\
\text { Silesian Upland }\end{array}$ & $\begin{array}{l}\text { Photograph with exposed mine shaft. } \\
\text { The middle part of the region, in which the Carboniferous rocks are found in its } \\
\text { geological structure, is rich in deposits of coal, zinc and lead ore. The } \\
\text { development of industry and settlement were the reasons why Silesian Upland } \\
\text { has become one of the most significantly transformed regions of Poland as a } \\
\text { result of human activity. }\end{array}$ \\
\hline
\end{tabular}


Table 5. Cont.

\begin{tabular}{|c|c|c|}
\hline TextbookMarking & Photograph/Figure & Description \\
\hline & $\begin{array}{l}\text { Photograph } \\
\text { Silesian Regional Costume* }\end{array}$ & $\begin{array}{l}\text { Silesians are a large and diverse ethnographic group. Some of the Silesians } \\
\text { living in mountain areas were shepherds, while those living in the lowlands } \\
\text { were engaged in agriculture. Later, another group of Silesians associated } \\
\text { with mining and industry was formed. }\end{array}$ \\
\hline & $\begin{array}{l}\text { Photograph } \\
\text { Mine Heaps }\end{array}$ & Mine heaps in Jastrzębie-Zdrój. \\
\hline & $\begin{array}{l}\text { Map } \\
\text { Industrial Districts in Poland }\end{array}$ & $\begin{array}{l}\text { GOP [Górnośląski Okręg Przemysłowy-Upper Silesian Industrial District]: } \\
\text { Raw materials: coal; branches of industry in GOP cities: energy, metallurgy, } \\
\text { machinery, automotive, electronic, technologically advanced, food. }\end{array}$ \\
\hline \multirow{6}{*}{5} & $\begin{array}{l}\text { Map } \\
\text { Distribution of Mineral Raw Materials of } \\
\text { Poland }\end{array}$ & Upper Silesia Basin, coal. \\
\hline & $\begin{array}{l}\text { Map } \\
\text { A Network of Large Cities and Urban } \\
\text { Complexes of Poland }\end{array}$ & $\begin{array}{l}\text { Urban agglomeration. } \\
\text { Katowice (Upper Silesia) Agglomeration, Katowice. }\end{array}$ \\
\hline & $\begin{array}{l}\text { Map } \\
\text { Main Industrial Districts of Poland }\end{array}$ & $\begin{array}{l}\text { Upper Silesian Industrial District. } \\
\text { Type: raw material. }\end{array}$ \\
\hline & $\begin{array}{l}\text { Map } \\
\text { Specialization of Districts and Major } \\
\text { Industrial Centers of Poland }\end{array}$ & $\begin{array}{l}\text { Upper Silesian (Katowice) industrial district: fuel and energy, metallurgy, } \\
\text { electro-machinery. }\end{array}$ \\
\hline & $\begin{array}{l}\text { Photograph } \\
\text { Katowice Steelworks }\end{array}$ & The entrance gate to Katowice Steelworks. \\
\hline & $\begin{array}{l}\text { Photograph } \\
\text { Park of Culture and Entertainment in } \\
\text { Chorzów }\end{array}$ & Mikołaj Kopernik Silesian Planetarium in the Silesian Park. \\
\hline \multirow{3}{*}{6} & $\begin{array}{l}\text { Map } \\
\text { Distribution of the Most Important Mineral } \\
\text { Raw Materials in Poland }\end{array}$ & $\begin{array}{l}\text { Upper Silesian Industrial District: } \\
\text { Coal. } \\
\text { Diagram of coal deposits formation. }\end{array}$ \\
\hline & $\begin{array}{l}\text { Map } \\
\text { Distribution of the Major Power Plants in } \\
\text { Poland }\end{array}$ & Łagisza, Jaworzno. \\
\hline & $\begin{array}{l}\text { Map } \\
\text { Industrial Districts in Poland in } 2007\end{array}$ & The Silesian-Kraków District. \\
\hline \multirow{5}{*}{7} & $\begin{array}{l}\text { Map } \\
\text { Distribution of Deposits of Mineral Raw } \\
\text { Materials in Poland }\end{array}$ & Coal, Katowice. \\
\hline & $\begin{array}{l}\text { Map } \\
\text { Population of Poland and Its Distribution in } \\
\text { the Largest Cities of Poland }\end{array}$ & Katowice, 10 in terms of population in Poland. \\
\hline & $\begin{array}{l}\text { Map } \\
\text { Polycentric Agglomeration (Upper Silesian } \\
\text { Industrial District) }\end{array}$ & Cities of the Conurbation. \\
\hline & $\begin{array}{l}\text { Map } \\
\text { The Largest Polish Power Plants }\end{array}$ & Rybnik, Jaworzno III, Łaziska, Siersza, Łagisza, Halemba, Blachownia. \\
\hline & $\begin{array}{l}\text { Photograph } \\
\text { Industrial Landscape of Upper } \\
\text { Silesia-Katowice Steelworks }\end{array}$ & The entrance gate to Katowice Steelworks. \\
\hline 8 & $\begin{array}{l}\text { Map } \\
\text { Deposits of Mineral Raw Materials in } \\
\text { Poland }\end{array}$ & Coal deposits. \\
\hline
\end{tabular}


Table 5. Cont.

\begin{tabular}{|c|c|c|}
\hline TextbookMarking & Photograph/Figure & Description \\
\hline \multirow{12}{*}{9} & $\begin{array}{l}\text { Figure } \\
\text { Polycentric Agglomeration }\end{array}$ & Cities of the agglomerations and their diversity in terms of population. \\
\hline & $\begin{array}{l}\text { Map } \\
\text { Extraction of Mineral Raw Materials in } \\
\text { Poland }\end{array}$ & Coal. \\
\hline & $\begin{array}{l}\text { Map } \\
\text { Thermal Power Plants }\end{array}$ & Rybnik, Łaziska Górne, Siersza, Będzin, Jaworzno. \\
\hline & $\begin{array}{l}\text { Map } \\
\text { Distribution of the Metallurgical Industry }\end{array}$ & $\begin{array}{l}\text { Steelworks in Bytom, Gliwice, Świętochłowice, Chorzów, Ruda Śląska, Katowice, } \\
\text { Będzin, Sosnowiec and Dabrowa Górnicza. }\end{array}$ \\
\hline & $\begin{array}{l}\text { Map } \\
\text { Distribution of the Electromechanical } \\
\text { Industry and Means of Transport }\end{array}$ & $\begin{array}{l}\text { Cities: Tarnowskie Góry, Piekary Ślaskie, Gliwice, Zabrze. Świętochłowice, } \\
\text { Katowice, Sosnowiec, Mysłowice, Dąbrowa Gornicza; Tychy, Gliwice. }\end{array}$ \\
\hline & $\begin{array}{l}\text { Map } \\
\text { Passenger Traffic at Polish Airports in } 2013 .\end{array}$ & Katowice (Pyrzowice) International Airport. \\
\hline & Landscape Map of the Silesian Upland & Upper Silesian Conurbation. Cities diversified in terms of population \\
\hline & $\begin{array}{l}\text { Photograph } \\
\text { A View from Piekary Śląskie Towards } \\
\text { Bytom. ** }\end{array}$ & $\begin{array}{l}\text { The air is not transparent here due to the high pollution of the atmosphere, } \\
\text { which affects the lack of clarity of part of the photograph. }\end{array}$ \\
\hline & $\begin{array}{l}\text { Photograph } \\
\text { Bielszowice Coal Mine in Ruda Śląska. }\end{array}$ & Mine seen from above. Mine shafts and conveyor belts clearly visible. \\
\hline & $\begin{array}{l}\text { Photograph } \\
\text { Former Coal Mining Heap in Rybnik }\end{array}$ & Conic heap. \\
\hline & $\begin{array}{l}\text { Photograph } \\
\text { Tarnowskie Góry-Market Square * }\end{array}$ & Evangelical Church of the Augsburg Confession. \\
\hline & $\begin{array}{l}\text { Photograph } \\
\text { Będzin-Royal Castle * }\end{array}$ & Body of the castle. \\
\hline
\end{tabular}

Figures distinguished in the entire set analyzed were highlighted in bold font: * figures with an unambiguously positive overtone; ${ }^{* *}$ figures with an unambiguously negative overtone; Source: own elaboration.

The image of the Upper Silesia Conurbation presented above is amplified by maps and photographs that supplements the description of the region (Table 5). Maps usually present coal deposits in the Upper Silesian Basin. Usually, there is only one city, i.e., Katowice. This city, as the largest one in the Conurbation, was also listed on the maps of the distribution of cities in Poland. Most of the textbooks contain a map of the Conurbation. In addition to the diversity of city size in terms of population number mentioned above, the type of the industry that dominates in a given city was indicated. Most photographs present the urban-industrial landscape with mines or steelworks in the foreground. There are also photographs presenting a landscape degraded with heaps or smog. In a few cases, the message of individual photographs is additionally amplified with a strictly unambiguous comment (this applies especially to textbook No. 9, Table 4). Photographs that present cultural features of the region (e.g., traditional Silesian costume) or interesting facilities ('Spodek' Sports and Entertainment Hall in Katowice, Silesian Stadium, Silesian Planetarium) are rare.

\section{Discussion}

One of the problems of stereotypical perception of a particular reality (including a tourist destination), is the fact that stereotypes do not present completely wrong and absent features of the reality, but, instead, they are focused too much on selected, often negative, features, ignoring other features. This problem can be easily found in the image of Upper Silesian Conurbation on the tourism market. It is extremely difficult to fight the negative stereotype of the region perceived as a dirty region and a polluted site with heavy industry, as the stereotype includes true history and presents an important part of the contemporary reality. However, the strength of the stereotype makes the rest of the reality, the rest which might be much more attractive for potential tourists, covered and unknown. This results in the region being perceived as uninterested and unattractive, not only for tourists.

The problem was identified many years ago and both local and regional authorities were struggling to solve it. Two opposite ways of these actions were identified. Katowice city authorities decided to minimize the influence of the heavy industry in the image of the city. That strategy was possible as the capital city of the Conurbation is the leader in economic transformation and the heavy industry plays 
nowadays only a marginal role in its development. On the contrary, regional authorities of the Silesian voivodeship choose the way to transform the most important weakness of the image into a major strength by presenting how industrial heritage can be attractive for visitors. Unfortunately, the results presented in the literature suggest that none of those strategies have brought the results expected.

School education in geography seems to be among the most underestimated factors that influence tourist destinations' image. The research presented proves that the features of the Conurbation that were often associated with the Upper Silesian Conurbation are almost the same features as presented in the textbooks they were learning from. The fact that the textbooks professionally prepared by experts and accepted by the Ministry of Education play such an important role in grounding the existing stereotypes instead of fighting them, might be surprising. It is difficult to suppose that their authors had no knowledge or good will. The reason is probably somewhere else and more complicated. During a few years of geographical education students have to learn many different aspects of physical and social geography of Poland, Europe and the rest of the world.

Geography of regions of Poland is just a small piece in that puzzle. In none of the textbooks analyzed, were all regions of Poland presented. Instead, particular regions were presented as examples of particular phenomena. Unfortunately, Upper Silesian Conurbation remains the most obvious example of industrialization and urbanization processes as well as of natural environment pollution and degradation. As a natural consequence of this structure of the textbook, other aspects of development of particular cities of the Conurbation are marginalized, or even absent. However, one may expect, that more space is going to be devoted to the current processes of diversification of economic and social activities leading to Conurbation's transformation into a modern metropolis. Even though those processes are discussed in the majority of books analyzed, their role in the description remains minor. Additionally, nowadays, the readers, especially the younger generation, will remember the content of the text mainly on two bases: the title and the pictures. In all examples, those two elements of the content of the textbooks amplify stereotypical perception of the Conurbation. In particular, pictures and descriptions that present examples of successful transition of degraded areas into new, modern parts of particular cities (like the Culture and Business Zones in Katowice located in the area of the former Katowice Coal Mine) are desired. One must remember that the aim of the textbooks is not promoting the image of one of the regions, but extending the students' knowledge. However, here we can see that the knowledge transferred to readers is not complete. Local and regional authorities should be interested in influencing the content of the future textbooks, but they do not have any formal tools to do so. So, if the negative stereotypes are grounded as early as in the school education, development and promotional activities of local and regional authorities do not have too much chances to succeed.

One more observation may weaken the conclusions derived from the results. The textbooks researched were published for the first time several years ago-between 2010 and 2012. Regarding the fact that the deindustrialization processes, which were visible earlier, were fostered within the last 10 years and all cited strategies of local and regional authorities were also announced between 2012 and 2017, it might be that the textbooks describe quite precisely the reality from the first decade of the century.

\section{Conclusions}

Organic image is perceived as an important factor of destination competitiveness. It is created by messages that potential tourists receive from autonomous sources, which means that those sources are not commercial and cannot be shaped by the destination's marketers. Usually media, including social media and word of mouth, are perceived and researched as the most influential examples of such autonomous sources of information. The presented study adds to that list another source of information which has been so far hardly noticed in the literature and its influence on destination image has not been researched. This source is school education, especially geographical education. The content analysis allowed to find that the textbooks presented almost exactly the same feature of 
the researched destination as it was earlier detected in the literature as the most common associations with the destination.

The research was conducted on the example of a single destination, and future research is necessary to confirm the relation between the image of a destination presented in geographical textbooks and the image tourists have regarding that destination. Possible confirmation of that relation would create a challenging task for destinations' marketers as the content of the textbooks is especially difficult to be influenced by purposeful marketing actions of how it was at least partially possible in the case of media. However, this might also be the reason why contemporary people may perceive the content of textbooks as especially trustworthy and even more reliable than media. Much more questions connected with destinations' marketing efficiency, the rules of creation of geographical textbooks and ethics should be posed if similar findings regarding the influence of those textbooks on destinations' images are also confirmed in other studies connected in different destinations.

Some interesting directions of future researches studies of international tourism should be pointed out. The presented research was concentrated on the image held by domestic tourists and on how a region of a country is presented in the textbooks in this country. The question, what kind of images of other countries are transmitted by Polish textbooks and how those images are repeated in Polish tourists' associations with those countries remains open. Information presented in geographical textbooks tend to be much more detailed regarding the home country and more general regarding the other states. How the fact influences the relation discovered in presented study seems to be an important part of future research in the field.

Author Contributions: M.S. and M.Ż. prepared the design of the research, conducted the research and developed the conclusions, M.S. prepared the description of the Upper Silesian Conurbation, M.Ż. prepared the literature review on the destination image formation.

Funding: This research was funded by Pedagogical University in Cracow, grant number WGB-BS-341/G/2018.

Conflicts of Interest: The authors declare no conflict of interest.

\section{References}

ARC Rynek i Opinia. 2014. Badanie ruchu turystycznego w województwie śląskim. Raport z badań dla Śląskiej Organizacji Turystycznej. Available online: http://www.silesia-sot.pl/wp-content/uploads/2012/01/raportbadanie-ruchu-tur-w-wojslaskim_2011.pdf (accessed on 14 June 2019).

Avraham, Eli, and Eran Ketter. 2017. Destination image repair while combatting crises: Tourism marketing in Africa. Tourism Geographies 19: 780-800. [CrossRef]

Avraham, Eli. 2018. Nation branding and marketing strategies for combatting tourism crises and stereotypes toward destinations. Journal of Business Research 36: 1-10. [CrossRef]

Baloglu, Seyhmus, and Ken W. McCleary. 1999. A model of destination image formation. Annals of Tourism Research 26: 868-97. [CrossRef]

Beerli, Asuncion, and Josefa D. Martín. 2004. Factors influencing destination image. Annals of Tourism Research 31: 657-81. [CrossRef]

Chen, Joseph S., and Cathy H. C. Hsu. 2000. Measurement of Korean tourists' perceived images of overseas destinations. Journal of Travel Research 38: 411-16. [CrossRef]

Chen, Po-Ju, and Deborah L. Kerstetter. 1999. International students' image of rural Pennsylvania as a travel destination. Journal of Travel Research 37: 256-66. [CrossRef]

Chen, Ching-Fu, and DungChun Tsai. 2007. How destination image and evaluative factors affect behavioral intentions? Tourism Management 28: 1115-22. [CrossRef]

Chen, Chun-Chu, Yueh-Hsiu Lin, and James F. Petrick. 2012. International stereotype and the collective construction of destination image. Tourism Analysis 17: 55-66. [CrossRef]

Chen, Chun-Chu, Ying-Hsiao (Rebecca) Lai, James F. Petrick, and Yueh-Hsiu Lin. 2016. Tourism between divided nations: An examination of stereotyping on destination image. Tourism Management 55: 25-36. [CrossRef] 
Chen, Chun-Chu, Jin Young Chung, Jie Gao, and Yueh Hsiu Lin. 2017. Destination familiarity and favorability in a country-image context: Examining Taiwanese travelers' perceptions of China. Journal of Travel E Tourism Marketing 34: 1211-23.

Chi, Christina Geng-Qing, and Hailin Qu. 2008. Examining the structural relationships of destination image, tourist satisfaction and destination loyalty: An integrated approach. Tourism Management 29: 624-36. [CrossRef]

Choi, Soojin, Xinran Y. Lehto, and Alastair M. Morrison. 2007. Destination image representation on the web: Content analysis of Macau travel related websites. Tourism Management 28: 118-29. [CrossRef]

Chung, Jin Young, Chun-Chu Chen, and Yueh-Hsiu Lin. 2016. Cross-strait tourism and generational cohorts. Journal of Travel Research 55: 813-26. [CrossRef]

Crompton, John L. 1979. An assessment of the image of Mexico as a vacation destination and the influence of geographical location upon that image. Journal of Travel Research 17: 18-23. [CrossRef]

Crouch, Geoffrey I., and J. R. Brent Ritchie. 1999. Tourism, competitiveness, and societal prosperity. Journal of Business Research 44: 137-52. [CrossRef]

Di Marino, Emma. 2008. The strategic dimension of destination image: An analysis of the French Riviera image from the Italian tourists' perceptions. Paper presented at 17th International Tourism and Leisure Symposium, Barcelona, Spain, May 21.

Echtner, Charlotte M., and J. R. Brent Ritchie. 1991. The meaning and measurement of destination image. Journal of Tourism Studies 2: 2-12.

Enright, Michael J., and James Newton. 2004. Tourism destination competitiveness: A quantitative approach. Tourism Management 25: 777-88. [CrossRef]

Fakeye, Paul C., and Johm L. Crompton. 1991. Image differences between prospective first-time and repeat visitors to the lower Rio Grande Valley. Journal of Travel Research 30: 10-16. [CrossRef]

Fu, Hui, Ben Haobin Ye, and Junzhi Xiang. 2016. Reality TV, audience travel intentions, and destination image. Tourism Management 55: 37-48. [CrossRef]

Gallarza, Martina G., Irene Gil Saura, and Haydée Calderón García. 2002. Destination image: Towards a conceptual framework. Annals of Tourism Research 29: 56-78. [CrossRef]

Gartner, William. C. 1994. Image formation process. Journal of Travel and Tourism Marketing 2: 191-215. [CrossRef]

Ghazali, Raslinda Mohd, and Liping Cai. 2014. Social media sites in destination image formation. In Tourism Social Media: Transformations in Identity, Community and Culture. Bingley: Emerald Group Publishing Limited, pp. 73-86.

Gunn, Clare A. 1972. Vacationscape: Designing Tourist Regions. Washington: Taylor \& Francis.

Hendel, Marek, and Michał Żemła. 2015. Zmiana wizerunku województwa ślasskiego pod wpływem rozwoju turystyki dziedzictwa przemysłowego. Prace Naukowe Uniwersytetu Ekonomicznego we Wrocławiu 379: 269-77. [CrossRef]

Kim, Sungeun-Eun, Kyung Young Lee, Soo Il Shin, and Sung-Byung Yang. 2017. Effects of tourism information quality in social media on destination image formation: The case of Sina Weibo. Information $\mathcal{E}$ Management 54: 687-702.

Kladou, Stella, and Eleni Mavragani. 2015. Assessing destination image: An online marketing approach and the case of TripAdvisor. Journal of Destination Marketing \& Management 4: 187-93.

Kock, Florian, Josiassen Alexander, and Assaf A. Georg. 2016. Advancing destination image: The destination content model. Annals of Tourism Research 61: 28-44. [CrossRef]

Lai, Wen-Hsiang, and Nguyễn Quang Vinh. 2012. A study of analyzing the selection of promotion activities and destination attributes in tourism industry in Vietnam from the perspective of tourism industrial service network (TISN). International Journal of Social and Human Sciences 6: 330-36.

Lepp, Andrew, Heather Gibson, and Charles Lane. 2011. Image and perceived risk: A study of Uganda and its official tourism website. Tourism Management 32: 675-84. [CrossRef]

Lopes, Sérgio Dominique Ferreira. 2011. Destination image: Origins, developments and implications. Revista de Turismo y Patrimonio Cultural 9: 305-15.

Millward-Brown SMG/KRC. 2010. Badanie ruchu turystycznego w województwie śląskim w 2010 roku (z uwzględnieniem turystyki biznesowej) oraz wizerunku województwa śląskiego i oceny działań promocyjnych. Available online: http://www.silesia-sot.pl/badanie-ruchu-turystycznego-w-wojewodztwieslaskim-w-2010-roku-2/2011/04/06 (accessed on 14 June 2019). 
Muhwezi, Deus K., Tom Baum, and Jockey B. Nyakaana. 2016. Dealing with negative symbolism of destinations with difficult heritage: Analysis of Ugandas image. Journal of Hospitality Management and Tourism 7: $33-42$.

Pike, Steven. 2018. Personal construct theory and the repertory test in destination image research. In Handbook of Research Methods for Tourism and Hospitality Management. Edited by Nunkoo Robin. Abingdon: Edward Elgar Publishing, pp. 222-30.

Pike, Steven, and Russell Mason. 2011. Destination competitiveness through the lens of brand positioning: The case of Australia's Sunshine Coast. Current Issues in Tourism 14: 169-82. [CrossRef]

Pike, Steven, and Chris Ryan. 2004. Destination positioning analysis through a comparison of cognitive, affective, and conative perceptions. Journal of Travel Research 42: 333-42. [CrossRef]

Piróg, Danuta. 2013. Are we becoming more culturally open by joining the EU countries?-The Polish perspective. In European Identity at the Crossroads. Edited by Aikaterini Klonari and Tatjana Resnik-Planinc. Berlin: LIT Verlag, pp. 99-122.

Resnik-Planinc, Tatjana. 2013. Perception of European identity among youth. In European Identity at the Crossroads. Edited by Aikaterini Klonari and Tatjana Resnik-Planinc. Berlin: LIT Verlag, pp. 3-20.

Rodríguez Campo, Lorena, Jose Antonio Fraiz Brea, and Diego Rodríguez-Toubes Muñiz. 2011. Tourist destination image formed by the cinema: Barcelona positioning through the feature film Vicky Cristina Barcelona. European Journal of Tourism, Hospitality and Recreation 2: 137-54.

Ross, Glenn F. 1993. Ideal and actual images of backpacker visitors to Northern Australia. Journal of Travel Research 32: 54-57. [CrossRef]

Selby, Martin, and Nigel J. Morgan. 1996. Reconstruing place image: A case study of its role in destination market research. Tourism Management 17: 287-94. [CrossRef]

Souiden, Nizar, Riadh Ladhari, and Nour E. Chiadmi. 2017. Destination personality and destination image. Journal of Hospitality and Tourism Management 32: 54-70. [CrossRef]

Statistical Yearbook of the Republic of Poland. 2017. Warsaw: Polish Statistical Office.

Strategia Promocji Katowic (Katowice Promotion Strategy). 2012. Katowice: Katowice City Hall. Available online: http://katowice.eu/SiteAssets/miasto/o-mieście/strategia-promocji-miasta/Strategia\%20Promocji\% 20Katowic\%2025.10.2012.pdf (accessed on 30 March 2019).

Strategia Komunikacji Marketingowej Województwa Śląskiego (Silesian Voivodeship Marketing Comminication Strategy). 2014. Katowice: Silesian Marshall Office. Available online: https://www.slaskie.pl/content/ strategia-komunikacji-marketingowej (accessed on 30 March 2019).

Sun, Minghui, Chris Ryan, and Steve Pan. 2015. Using Chinese travel blogs to examine perceived destination image: The case of New Zealand. Journal of Travel Research 54: 543-55. [CrossRef]

Szubert, Mariusz, and Michał Żemła. 2019. Wizerunek miast konurbacji górnośląskiej-wyzwanie przełamywania stereotypów. Annales Universitatis Paedagogicae Cracoviensis Studia Geographica 13: 57-69.

Tamajón, Lluis Garay, and Gemma Cànoves Valiente. 2017. Barcelona seen through the eyes of TripAdvisor: Actors, typologies and components of destination image in social media platforms. Current Issues in Tourism 20: 33-37. [CrossRef]

Tapia, Gema P. 2017. The Role of Familiarity in the Destination Image: A Case Study of South Korea. European Journal of East Asian Studies 16: 296-316. [CrossRef]

Tasci, Asli D. A., and William C. Gartner. 2007. Destination image and its functional relationships. Journal of Travel Research 45: 413-25. [CrossRef]

Tkocz, Maria. 2015. Tradycyjny okręg przemysłowy z perspektywy 25-lecia funkcjonowania w gospodarce rynkowej w Polsce. Przykład Górnośląskiego Okręgu Przemysłowego. Prace Komisji Geografii Przemystu Polskiego Towarzystwa Geograficznego 29: 112-26.

TNS Polska. 2014. Badanie wizerunku województwa śląskiego. In Raport z badania TNS Polska Oddział Katowice dla DEMO Effective Launching. Available online: https://docplayer.pl/3373871-Badanie-wizerunku-wojewodztwaslaskiego-raport-z-badania-tns-polska-oddzial-katowice-dla-demo-effective-launching.html (accessed on 30 March 2019).

Tourism Development Strategy in the Silesian Voivodeship 2020+. 2017. Katowice: Silesian Marshall Office. Available online: https://www.slaskie.pl/content/strategia-rozwoju-turystyki (accessed on 30 March 2019).

Voivodeship Development Strategy. 2013. Katowice: Silesian Marshall Office. Available online: https://www. slaskie.pl/content/strategia-rozwoju-wojewodztwa-slaskiego-slaskie-2020 (accessed on 30 March 2019). 
Wang, Dan, HweeLeng Chan, and Steve Pan. 2015. The impacts of mass media on organic destination image: A case study of Singapore. Asia Pacific Journal of Tourism Research 20: 860-74. [CrossRef]

Zuzańska-Żyśko, Elżbieta. 2016. Procesy metropolizacji. Teoria i praktyka. Warszawa: Wydawnictwo Naukowe PWN, p. 472. 